\title{
Fracture surface of recycled AlSi10Mg cast alloy
}

Mária Farkašová, Eva Tillová, Mária Chalupová

Department of Materials Engineering, Faculty of Mechanical Engineering, University of Žilina. Univerzitná 8215/1, 010 26, Žilina, Slovak Republic. maria.farkasova@fstroj.uniza.sk

Recycled aluminium alloys are made out of aluminium scrap (new or old) and workable aluminium garbage by recycling. Due to the increasing production of recycled aluminium cast alloys is necessary to ensure their strict metallurgical control. The mechanical properties and the microstructure character depends on the chemical composition; melt treatment conditions, solidification rate, casting process and the applied thermal treatment. The mechanical properties depend on the morphologies, type and distribution of $\mathrm{Si}, \mathrm{Cu}, \mathrm{Mg}$ and $\mathrm{Fe}$-phases, on the grain size, DAS and porosity distribution. Improvement of mechanical properties and structure of Al-alloys can often significantly increase the using lifetime of a casting. Different elements are added to achieve the optimum casting and mechanical properties. Modification can be achieved by several methods as faster solidification, mould vibration, melt agitation in mushy state and melt inoculation by using chosen elements like Sr, Na, Sb etc. Present work is focused on study of the effect of Sr-modification on the structure and mechanical properties of recycled AISi10Mg cast alloy. For study and identification of intermetallic phases' was utilized standard (HF), colour (MA) and deep etching (HCl) in order to reveal the three-dimensional morphology of the silicon particles and intermetallic phases. For element composition of the specimen was used X-ray (EDX) analysis. Finally, the effect of modification on silicon morphology and fracture surface was examined.

Keywords: fracture surface, recycled Al-Si cast alloys, fractographic analysis, intermetallic phases

Acknowledgements

This work has been supported by Scientific Grant Agency of Ministry of Education of Slovak republic No1/0841/11 and project ÉU - ITMS: 26110230004.

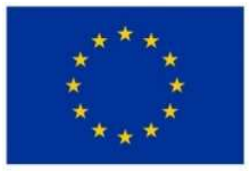

Európska únia

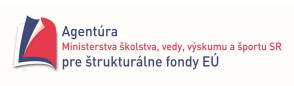

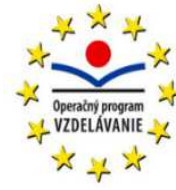

"Modern education for knowledge society / Project is supporting by financial source of European Union"

Project: Systematization of the Advanced Technologies and Knowledge transfer between industry and universities ITMS: 26110230004

\section{References}

[1] MAHFOUD, M., PRASADA RAO, A. K. et all. (2010): The role of thermal analysis in detecting impurity levels during aluminum recycling. J Therm Anal Calorim, 100, pp. 847-851.

[2] DAS, S. K., GREEN, J. A. S. (2010): Aluminum Industry and climate change-assessment and responses. JOM, 2010, Vol. 62, No. 2, pp. 27-31 www.tms.org/jom.html.

[3] IBRAHIM, M. F., SAMUEL, E., SAMUEL, A. M., AL-AHMARI, A. M. A., SAMUEL, F. H. (2011): Impact toughness and fractography of Al-Si-Cu-Mg base alloys. Materials \& Design, Volume 32, Issue 7, pp. 39003910 .

[4] TIllová, E., CHAluPOVÁ, M., HURTAlOVÁ, L., ĎURINÍKOVÁ, E. (2011). Quality control of microstructure in recycled Al-Si cast alloys. Manufacturing Technology, Vol. 11, pp. 70-76.

[5] MICHNA et al. (2007): Aluminium materials and technologies from A to Z. Adin, s. r. o., Prešov, ISBN 978-8089244-18-8

[6] TILlOVÁ, E., CHALUPOVÁ, M. (2009). Structural analysis of Al-Si alloys. EDIS Žilina (in Slovak).

[7] ASM Handbook (2002). Vol.15 - Casting, ASM International.

[8] KNUUTINEN, A., NOGITA, K., McDONALD, S. D., DAHLE, A. K. (2001). Modification of Al-Si alloys with $\mathrm{Ba}, \mathrm{Ca}, \mathrm{Y}$ and Yb. Journal of Light Metals, 1, pp. 229-240.

[9] COMALCO (1997). Modification of foundry Al-Si alloys. Technical report No. 4., Comalco Aluminum Limited. Brisbane, Australia.

[10] KAUR, P.K., PANDEY, O. P. (2010): Structural and age hardening characteristics of near eutectic Al-Si alloys. International Journal of Materials Research, 101, 9, pp. 1158-1165

[11] STřIHAVKOVÁ, E., WEISS, V. (2012): The Identification of the structures new type Al-Si-Mg Ca alloys with 
different Ca content using of the color metallography. Manufacturing technology, Vol. 12, No. 13, pp.

[12] PEZDA, J. (2009): Effect of modifying process on mechanical properties of EN AB-42000 silumin cast into sand moulds. Archives of Foundry Engineering, Vol. 9, 4, pp. 187-190.

[13] BOLIBRUCHOVÁ, D., BRÚNA, M. (2013): Influencing the crystallization of secondary alloy AlSi6Cu4 with strontium. Manufacturing technology, Vol. 13, No. 1, 2013, pp. 7-14.

[14] FARKAŠOVÁ, M., TILLOVÁ, E., CHALUPOVÁ, M. (2013): Modification of Al-Si-Cu cast alloy. FME Transactions, New series, Vol. 41, 3, pp. 210-215.

[15] TILLOVÁ, E., FARKAŠOVÁ, M., CHALUPOVÁ, M. (2013): The role of antimony in modifying of Al-Si-Cu cast Alloy. Manufacturing technology, Vol. 13, 1, pp. 109-114.

[16] MAKHLOUF, M. M., GUTHY, H. V. (2001): The aluminum-silicon eutectic reaction: mechanisms and crystallography. Journal of Light Metals, 1, pp. 199-218.

[17] MICHNA, Š., NÁPRSTKOVÁ, N. (2012): The Application of Fractography to Resolve the Issue of Castings Quality in the Automotive Industry. Manuf. and Ind. Eng., 11 (3), p. 50-53.

[18] WARMUZEK, M. (2004): Aluminum-Silicon-Casting Alloys: Atlas of Microfractographs, ASM International, Materials Park.

[19] MICHNA, Š., NÁPRSTKOVÁ, N. (2012). Research into the causes cracking of aluminum alloys of Al-Cu during mechanical machining. Manufacturing Technology. Volume 12, June 2012, pp. 47-51. 